\title{
Examining the Competitiveness in European Banking Industry with Fuzzy AHP and Fuzzy TOPSIS Approaches
}

\author{
Serhat YÜKSEL ${ }^{1}$ \\ Hasan DINÇER ${ }^{2}$
}

\begin{abstract}
This study aims to evaluate the competitiveness in European banking industry. For this purpose, 5 European countries, which have the highest GDP, are considered in this study that are Germany, France, United Kingdom, Italy, and Spain. Moreover, 6 different criteria are selected based on the literature review. Fuzzy AHP method is considered to understand the significance of the dimensions and criteria. On the other side, fuzzy TOPSIS model is used to rank these 5 European countries according to competitiveness in the banking industry. The findings show that low cost is the most significant criterion for this condition. In addition to this issue, it is also concluded that Germany and France are on the first ranks regarding the competitiveness in the banking industry. Hence, it is recommended that European banks should firstly concentrate on the cost effectiveness in order to increase the competitive power. In this framework, a detailed analysis should be conducted to understand which cost types are greater in comparison with the others. Hence, it can be possible to minimize the costs of the banks so that these banks can offer lower prices to their customers. This situation has a positive impact on the competitive power of the banks.
\end{abstract}

Keywords: European Banking Sector; Competitiveness; Fuzzy AHP; Fuzzy TOPSIS

\author{
Avrupa Bankacılık Sektöründeki Rekabet Gücünün Bulanık AHP ve Bulanık TOPSIS \\ Yaklaşımlarıyla İncelenmesi
}

$\ddot{O} z$

Bu çalışma, Avrupa bankacıllk sektöründeki rekabet gücünü değerlendirmeyi amaçlamaktadır. Bu doğrultuda, en yüksek GSYIH'ye sahip 5 Avrupa ülkesi olan Almanya, Fransa, Birleşik Krallık, İtalya ve İspanya bu çalışmanın kapsamına dahil edilmişstir. Ayrıca, literatür taraması sonuçlarına göre, 6 farklı kriter seçilmiştir. Bulanık AHP yöntemi ile boyutların ve kriterlerin önem ağırlkkları hesaplanmıştır. Öte yandan, bulanık TOPSIS modeli, bankacllı sektöründeki rekabet gücüne göre bu 5 Avrupa ülkesini siralamak için kullanllmaktadır. Bulgular düşük maliyetin bu durum için en önemli kriter olduğunu göstermektedir. Bu konuya ek olarak, Almanya ve Fransa'nın da bankacllık sektöründe rekabet gücü açısından ilk siralarda yer aldığı sonucuna varılmıştır. Bu nedenle Avrupa bankalarının rekabet gücünü artırmak için öncelikle maliyet etkinliğine odaklanmaları önerilmektedir. Bu çerçevede, hangi maliyet türlerinin diğerlerine göre daha yüksek olduğunu anlamak için ayrıntıll bir analiz yapılmalıdır. Böylelikle, bu bankaların müssterilerine daha düşük fiyatlar sunabilmeleri için bankaların maliyetlerini minimize edebilmek mümkün olabilecektir. Bu durum, bankalarin rekabet gücünün artmasina katkı sağlayacaktır.

Anahtar Kelimeler: Avrupa Bankacılı Sektörü; Rekabet Gücü; Bulanık AHP; Bulanık TOPSIS

\footnotetext{
1Assoc. Prof., İstanbul Medipol University, The School of Business, İstanbul, Turkey, email: serhatyuksel@medipol.edu.tr; ORCID: 0000-0002-9858-1266

2 Prof., İstanbul Medipol University, The School of Business, İstanbul, Turkey, email: hdincer@medipol.edu.tr; ORCID: 0000-0002-8072-031X
}

Makale Geliş Tarihi: 20.12.2020, Makale Kabul Tarihi: 18.04.2021

ARAŞTIRMA MAKALESİ (Research Article)

* Bu makale intihal programında taranmış ve en az iki hakem incelemesinden geçmiştir. (This article has been scanned via a plagiarism software and reviewed by at least two referees).

Doi: https://doi.org/10.51524/uhusbad.843949 


\section{Introduction}

The competition in the banking industry increased very much especially after the globalization. The main reason behind this aspect is that globalization has a strong and positive impact on the international trade volume. This issue creates an opportunity for the companies to enter other countries to have new customers. As a result of this period, many international companies started to operate in lots of the countries (Claessens and Van Horen, 2015). This condition has many advantages for the economies. Firstly, it contributes the trade volume of these countries. Another important benefit is that it increases job opportunities for the citizens, so it is obvious that unemployment problem can be decreased. Despite these benefits, globalization also leads to some problems for the economies (Kalkavan and Ersin, 2019). For instance, because many different companies entered to various countries, there is significant competition in almost all industries.

Banking is an important industry which has high competition because of the globalization. Since international trade volume went up very much in the world, there was a need for an institution which regulates this operation between the countries because each country can have different rules (Eti et al., 2020). Banks started to play an essential role for this purpose while making effective connection with the banks of the other countries (Ghosh, 2017; Kalkavan et al., 2020). With the help of this situation, money can be transferred very easily. In addition to this situation, especially international banks preferred to enter other countries to reach new customers so that they gained a chance to increase their market share (Dinçer et al., 2017; Eti et al., 2019). All these aspects cause competition to increase in the banking industry. In this issue, small domestic banks were influenced from this situation very negatively because it is very difficult to compete with these big banks.

European banking industry also had significant competition in the last years. There are many different reasons for this situation. For instance, Europe has a high importance with respect to the location. Because it is very near to the many different continents, it attracted the attention of the international banks. Therefore, these banks preferred to enter this market to make effective connections with other countries (Jun et al., 2020). Furthermore, most of the European countries have developed economies, such as France, Germany, Italy. It means that these countries have more developed industry in comparison with others. In other words, many big companies in different industries locate in European regions (Chiaramonte and Casu, 2017). Hence, most of the banks are willing to work with these big companies. These issues have an important effect for the increase in the competition in the European banking industry.

As it was emphasized from previous paragraphs, competition decreased the profitability of especially small domestic banks. Thus, these banks must take some actions in order to cope with this competition. However, this competition is also dangerous for the big banks. The reason is that if they cannot have competition power, they can also go bankrupt. In summary, some strategies should be developed by European banks to survive in such a competitive environment (Fernández and Garza-García, 2015). For example, technological investment is a factor that differentiates banks from others. In this context, the fact that the IT program used by the bank and alternative distribution channels in accordance with modern technology will increase the competitiveness of these banks (Dinçer et al., 2016). On the other side, customer satisfaction may be another important issue which has an increasing effect on the competitive power. For this purpose, customers' expectations should be identified firstly, and necessary actions should be implemented to satisfy these expectations.

In this study, it is aimed to assess the competitiveness of the European banking industry. Within this context, 5 biggest economies of Europe (Germany, France, United Kingdom, Italy, and Spain) are taken into consideration. In the first stage of the analysis, determinants of the competition in the banking industry are identified. In this scope, 6 different criteria are selected ( 3 internal and 3 external) because of the literature review. After that, fuzzy AHP model is considered to understand the significance of these dimensions and criteria. In the final process of the analysis, fuzzy TOPSIS approach is used to rank these 5 different European countries according to their competitive power performance.

This study is thought to contribute to the literature in many respects. First, the size and criteria set that will affect the competitiveness of banks have been determined. On the other hand, these factors are weighted for the European banking sector. Therefore, this list is a guide for all managers and academics 
in banks. Within this framework, the top management of banks can benefit from these factors in their strategic decisions. In addition, the fuzzy AHP and fuzzy TOPSIS models were considered for the first time in the competition analysis in the European banking sector. It has been concluded that this situation completes an important deficiency in the literature.

This study basically consists of 5 different sections. In the first part, important issues such as the significance of the banking sector and competition in this sector have been taken into consideration. In the second part of the study, a literature review was made. In addition, the third section includes the methods used in the study. On the other hand, the analysis results are shared in the fourth part of the study. In the last part of the study, suggestions are given.

\section{Competition in the Banking Industry}

Lots of the researchers underlined that cost efficiency is an important factor for the banks to increase the competitive power. Banks can achieve a price advantage over their competitors by lowering their costs while performing their operations (Schliephake, 2016; Yuliansyah et al., 2016; Bereznoi, 2015). The main reason for this is that banks can lower their prices if costs can be reduced. This increases the banks' preference for customers (Hu and Xie, 2016; Burks et al., 2018). For instance, Hes and Jílková (2016) aimed to evaluate the competitiveness of the banking industry in the Czech Republic. They concluded that banks should firstly concentrate on the cost leadership strategy to increase their competitive power. Sircar et al. (2015) and Zuhroh et al. (2015) also underlined the significance of the same issue for different regions, such as India and Indonesia. Parameswar et al. (2017) and Nowakowski and Karasiewicz (2016) also stated that cost effectiveness is an important issue to survive in competitive banking industry.

Another important subject that affects the competition in the banking industry is the organizational efficiency. For this purpose, the departments of the banks should be designed very carefully to increase the efficiency of the banking operations (Alshubaily and Altameem, 2017; Wu and Chiu, 2015). For example, it is important to determine the short-, medium- and long-term strategies of the bank and to design the organizational structure in accordance with these strategies. In parallel, the job description of the personnel at the bank is expected to be in line with these strategies (Y1lmaz, 2016; Dinçer et al., 2016b). In this process, opening unnecessary departments and employing people who are not competent in departments will decrease the efficiency of banks (Gunasekaran et al., 2017; Dinçer et al., 2019f). Within this framework, Setyawati et al. (2019) focused on the performance of the banking industry in Indonesia. They defined that organizational efficiency brings a competitive advantage to the banks. Parallel to this research, Kasasbeh et al. (2017) and Sudha and Kavita (2019) identified this issue in their studies by using different methodologies.

Technological development has come to the forefront as an important factor affecting the competitiveness of the banking sector in many studies. Banks can make their internal communications more active by investing in technology (Dinçer and Yüksel, 2018). On the other hand, with the help of this technological development, alternative distribution channels such as ATM and internet banking can become more useful (Dinçer et al., 2019e). This will make the banks preferable to the customers (Vozková and Teplý, 2018; Kasımoğlu et al., 2016; Litvintseva and Gakhova, 2016). Furthermore, the use of alternative distribution channels will reduce the burden on the branches of banks (Tadeu et al., 2019; Yüksel et al., 2015). In addition, Raičević et al. (2016), Karabag (2019) and Bapat (2017) made an analysis for developing countries and reached the conclusion that banks should firstly give importance to the technological development to increase the competitive power.

According to many researchers, meeting customer expectations is one of the most prominent factors in terms of the competitiveness of banks. As with all other companies, banks offer their products to customers (Agolla et al., 2018). Therefore, it is important that the products and services offered by banks address customers' expectations. In this respect, banks should first understand the expectations of their customers clearly (Basheer et al., 2015; Rahman, 2017; Dinçer et al., 2017b). Otherwise, these products and services will not be preferred by customers and this will adversely affect the profitability of banks (Adams et al., 2016; Gozman et al., 2018). In this context, Kotarba (2016) tried to evaluate the customer relationship management performance in retail banking industry. It is determined that customers should be satisfied for the sustainable profitability of the banks. Moreover, Suhidayat et al. (2016) made an 
analysis for Indonesian banking industry and underlined the significance of the similar issue. Also, Paul et al. (2016) defined that service quality is an essential factor for customer satisfaction in private and public sector banks.

As a result of this extensive literature review in the banking sector, it has been determined that there are many different studies on this subject. Some of the studies emphasized that banks should first reduce their costs to gain competitive advantage. Some researchers stated that the organizational structure of the bank should be designed more effectively to increase competitiveness. In addition, there have been advocates that factors such as technological development and customer satisfaction are important in this context. In the mentioned studies, it is seen that methods such as regression and correlation are also preferred while conducting survey analysis. Therefore, because of this detailed examination, it is thought that considering a different method or scope in a new study will bring originality to the literature.

\section{Methodology}

\subsection{Fuzzy AHP}

Analytic hierarchy process is introduced by Thomas Saaty in 1977 for evaluating the items with pairwise comparisons (Saaty, 1977). The method uses the hierarchical roles in the comparisons between the factors by considering the one-way interaction role. The method is widely applied for weighting the criteria and alternatives and ranking among the items (Dinçer and Hacıoglu, 2013). In this study, the method of Chang (1996) is used and the produce of fuzzy AHP can be summarized as

Step 1. Construct a pair-wise comparison matrix: Fuzzy numbers are used for constructing the matrix as seen below

$$
\tilde{A}=\left[\begin{array}{cccccc}
1 & \tilde{a}_{12} & \tilde{a}_{13} & & \cdots & \tilde{a}_{1 m} \\
\tilde{a}_{21} & 1 & \tilde{a}_{23} & & \cdots & \tilde{a}_{2 m} \\
\tilde{a}_{31} & \tilde{a}_{32} & 1 & & \cdots & \tilde{a}_{3 m} \\
\vdots & \vdots & \vdots & \ddots & & \vdots \\
\tilde{a}_{n 1} & \tilde{a}_{n 2} & \tilde{a}_{n 3} & & \cdots & 1
\end{array}\right]
$$

Step 2. Calculate the fuzzy synthetic extent (Si) as

$$
S_{j}=\sum_{j=1}^{m} M_{g i}^{j} \otimes\left(\sum_{i=1}^{n} \sum_{j=1}^{m} M_{g i}^{j}\right)^{-1}
$$

The value of $\sum_{j=1}^{m} M_{g i}^{j}$ is given below

$$
\sum_{j=1}^{m} M_{g i}^{j}=\left(\sum_{j=1}^{m} l_{j}, \sum_{j=1}^{m} m_{j}, \sum_{j=1}^{m} u_{j}\right)
$$

where, $\mathrm{l}, \mathrm{m}$ and $\mathrm{u}$ are a set of triangle fuzzy numbers and the value of $\left[\sum_{i=1}^{n} \sum_{j=1}^{m} M_{g i}^{j}\right]^{-1}$ is calculated as follows

$$
\begin{aligned}
& \sum_{i=1}^{n} \sum_{j=1}^{m} M_{g i}^{j}=\left(\sum_{j=1}^{m} l_{i}, \sum_{j=1}^{m} m_{i}, \sum_{j=1}^{m} u_{i}\right) \\
& {\left[\sum_{i=1}^{n} \sum_{j=1}^{m} M_{g i}^{j}\right]^{-1}=\left(\frac{1}{\sum_{i=1}^{n} u_{i}}, \frac{1}{\sum_{i=1}^{n} m_{i}}, \frac{1}{\sum_{i=1}^{n} l_{i}}\right)}
\end{aligned}
$$


Step 3: Determine the degree of possibility of $M 1(11, \mathrm{~m} 1, \mathrm{u} 1) \geq \mathrm{M} 2(12, \mathrm{~m} 2$, u2): “d” represents the ordinate of the point $\mathrm{D}$ which is the maximum intersection point of $\mu_{M_{1}}$ and $\mu_{M_{2}}$.

$$
\begin{aligned}
& V\left(M_{2} \geq M_{1}\right)=\sup \left[\min \left(\mu_{M_{1}}(x), \mu_{M_{2}}(y)\right]\right. \\
& V\left(M_{2} \geq M_{1}\right)=\operatorname{hgt}\left(M_{1} \cap M_{2}\right)=\mu_{M_{2}}(d) \\
& =\left\{\begin{array}{ccc}
1, & \text { if } & m_{2} \geq m_{1}, \\
0, & \text { if } & l_{1} \geq u_{2}, \\
\frac{l_{1}-u_{2}}{\left(m_{2}-u_{2}\right)-\left(m_{1}-l_{1}\right)} & & \text { otherwise }
\end{array}\right.
\end{aligned}
$$

Step 4: Compute the degree of possibility as

$\mathrm{V}\left(\mathrm{M} \geq \mathrm{M}_{1}, \mathrm{M}_{2}, \ldots \mathrm{M}_{\mathrm{k}}\right)=\mathrm{V}\left[\left(\mathrm{M} \geq \mathrm{M}_{1}\right)\right.$ and $\left(\mathrm{M} \geq \mathrm{M}_{2}\right)$ and $\left.\ldots\left(\mathrm{M} \geq \mathrm{M}_{\mathrm{k}}\right)\right]=\min \mathrm{V}\left(\mathrm{M} \geq \mathrm{M}_{\mathrm{i}}\right)$

where $d^{\prime}\left(A_{i}\right)=\min V\left(S_{i} \geq S_{k}\right)$ and $W^{\prime}=\left(d^{\prime}\left(A_{1}\right), d^{\prime}\left(A_{2}\right), \ldots, d^{\prime}\left(A_{n}\right)\right)^{T} \mathrm{i}=1,2,3 \ldots \mathrm{n}$

Step 5: Normalize the factors. The process is employed by the following formula

$$
w=\left(d\left(A_{1}\right), d\left(A_{2}\right), \ldots, d\left(A_{n}\right)\right)^{T}
$$

This analysis was preferred in a lot of different studies in the literature, such as water loss management (Zyoud et al., 2016), risk analysis (Mangla et al., 2015), urban planning (Mosadeghi et al., 2015), performance measurement (Chen et al., 2015; Perçin and Aldalou, 2018), supplier selection (Awasthiet al., 2018), landfill site selection (Beskese et al., 2015).

\subsection{Fuzzy TOPSIS}

Fuzzy TOPSIS is firstly used by Hwang and Yoon in 1981 to order of preference by the similarities to the ideal solution (Hwang and Yoon, 1981). The method uses the optimal solutions by measuring the distances from the negative and positive ideal solutions. For that, the method is widely applied for the complex decision problems (Dinçer and Yuksel, 2019). The steps of fuzzy TOPSIS can be defined as

Step 1. Construct the fuzzy decision matrix: Linguistic evaluations of each criterion are converted into the triangular fuzzy numbers for the alternatives. Thus, fuzzy decision matrix is provided. In this process, averaged values of decision makers are considered as seen in the following equation.

$$
\tilde{X}_{i j}=\frac{1}{k}\left(\tilde{X}_{i j}^{1}+\tilde{X}_{i j}^{2}+\tilde{X}_{i j}^{3}+\ldots \ldots+\tilde{X}_{i j}^{k}\right)
$$

where $\widetilde{X}_{i j}^{k}$ is the evaluation result of a decision maker.

Step 2. Normalize the fuzzy decision matrix: Normalization procedure is given by the formulas

$$
\begin{gathered}
\tilde{r}_{i j}=\left(\frac{a_{i j}}{c_{i j}^{*}}, \frac{b_{i j}}{c_{i j}^{*}}, \frac{c_{i j}}{c_{i j}^{*}}\right) \\
c_{i j}^{*}=\sqrt{\sum_{i=1}^{m} c_{i j}^{2}}
\end{gathered}
$$

Step 3. Define the positive and negative ideal solutions: the positive $\left(A^{+}\right)$and negative $\left(A^{-}\right)$ideal solutions are defined as follows

$$
A^{+}=\left(\tilde{v}_{1}^{*}, \tilde{v}_{2}^{*}, \tilde{v}_{3}^{*}, \ldots \tilde{v}_{n}^{*}\right) \text { and } A^{-}=\left(\tilde{v}_{1}^{-}, \tilde{v}_{2}^{-}, \tilde{v}_{3}^{-}, \ldots \tilde{v}_{n}^{-}\right)
$$

Step 4. Compute the distances from the ideal solutions: The distances from the positive and negativeideal solution are presented with the following equations

$$
\begin{aligned}
& D_{i}^{*}=\sum_{j=1}^{n} d\left(\tilde{v}_{i j}, \tilde{v}_{j}^{*}\right) \\
& D_{i}^{-}=\sum_{j=1}^{n} d\left(\tilde{v}_{i j}, \tilde{v}_{j}^{-}\right)
\end{aligned}
$$


Step 5. Rank the alternatives: the values of closeness coefficient are employed to rank the set of alternatives by

$$
C C_{i}=\frac{D_{i}^{-}}{D_{i}^{+}+D_{i}^{-}}
$$

There are also many different studies in the literature by considering fuzzy TOPSIS approach. These studies focused on many different purposes. For example, Şengül et al. (2015), Guo and Zhao (2015) and Ervural et al. (2018), Yüksel et al. (2019), Wang et al. (2020) and Dinçer and Yüksel (2019a,b,c,d) made a study about energy industry whereas Gupta and Barua (2017) and Lima-Junior and Carpinetti (2016) looked at the supplier selection. On the other side, Zhong et al. (2020), Yuan et al. (2020), Qiu et al. (2020) and Li et al. (2020) focused on the renewable energy investments with the help of TOPSIS methodology.

\section{Analysis}

An integrated approach is applied for evaluating the competitiveness of European banking industries. For this purpose, several steps are defined respectively as follows.

Step 1. Define the problem of competitiveness in the banking industry: In the literature, there are various studies that focus on the different perspectives of competitiveness in the banking industry. Table 1 represents that selected determinants of competition for the banking industry based on literature review.

Table 1. Determinants of Competition for Banking Industry

\begin{tabular}{|c|c|l|}
\hline \multirow{4}{*}{ Dimensions } & \multicolumn{1}{|c|}{ Criteria } & \multicolumn{1}{c|}{ Supported Literature } \\
\hline \multirow{4}{*}{ Internal (Dimension 1) } & Low Cost (Criterion 1) & $\begin{array}{l}\text { (Dal Colle, 2018; Kim et al. } \\
\text { 2015) }\end{array}$ \\
\cline { 2 - 3 } & $\begin{array}{c}\text { Organizational efficiency } \\
\text { (Criterion 2) }\end{array}$ & $\begin{array}{l}\text { Tan and Floros, 2018; Vera- } \\
\text { Gilces et al. 2019) }\end{array}$ \\
\cline { 2 - 3 } & $\begin{array}{c}\text { Technological infrastructure } \\
\text { (Criterion 3) }\end{array}$ & $\begin{array}{l}\text { (Vives, 2019; Bos et al. 2013; } \\
\text { Li et al., 2021) }\end{array}$ \\
\hline \multirow{3}{*}{ External (Dimension 2) } & $\begin{array}{c}\text { Consistency of customer } \\
\text { expectations (Criterion 4) }\end{array}$ & $\begin{array}{l}\text { (Stenbacka and Takalo, } \\
\text { 2019; Dinçer et al. 2019; } \\
\text { Kalkavan, 2020) }\end{array}$ \\
\cline { 2 - 3 } & $\begin{array}{c}\text { Innovative services in } \\
\text { accordance with market } \\
\text { trends (Criterion 5) }\end{array}$ & $\begin{array}{l}\text { (Cornaggia et al. 2015; } \\
\text { Fontin and Lin, 2019) }\end{array}$ \\
\cline { 2 - 3 } & $\begin{array}{c}\text { Competitive Pricing Policies } \\
\text { (Criterion 6) }\end{array}$ & $\begin{array}{l}\text { (Coccorese and Pellecchia, } \\
\text { 2013; Carbó et al. 2009). }\end{array}$ \\
\hline
\end{tabular}

Internal and external dimensions are defined for the perspectives of banking competition. Internal dimension is divided into 3 criteria entitled as low cost (criterion 1), organizational efficiency (criterion 2), and technological infrastructure (criterion 3) with the supported literature. For that, Dal Colle (2018) provides an extended model that defines the linkage between cost structure and competition in the banking industry. Kime et al. (2015) analyze the relationship between financial development and cost of equity and, find some evidence that could cause to decrease the banking development. Tan and Floros, (2018) study on the interrelationships of risk, competition, and efficiency for the banking industry as well as highlighting the operational risks derived from the organizational behaviors. Vera-Gilces et al. (2019) propose a model with the combination of competition, market power, and industrial organization. Vives, (2019) presents a new outlook for the competition and stability in the modern banking with the rising effects of digital technologies. Bos et al. (2013) discuss the competition and innovation issues with the bank technology gap.

The criteria of external dimension are represented as Consistency of customer expectations (Criterion 4), innovative services in accordance with market trends (Criterion 5), competitive Pricing Policies (Criterion 6) based on the literature review. Accordingly, Stenbacka and Takalo (2019) conclude that 
effect of the competition depends on the reducing the costs and the customer relationship is highly related to the competitional environment. Dinçer et al. (2019) examine a balanced scorecard-based evaluation for the competition of banking industry by considering the customer expectations. Cornaggia et al. (2015) argue that the competition in the banking industry could cause some effects on the innovative targets. Fontin and Lin, (2019) define the major factors of financial innovation as the combination of competition, financial inclusion, and banking access. Coccorese and Pellecchia, (2013) assess the effects of market power in case of price divergences for the banking industry. Carbó et al. 2009 present the banking pricing power as a tool of banking market competition.

However, 5 countries that have the highest rank in the gross domestic product for the European Zone are selected for ranking alternatives. These countries are United Kingdom (alternative 1), Germany (alternative 2), Italy (alternative 3), France (alternative 4), and Spain (alternative 5).

Step 2. Select the decision makers and obtain the linguistic evaluations for the criteria and dimensions: 4 Decision makers that have at least ten-year experiences in the field of banking and finance are appointed to get their linguistic choices for each criterion and alternatives. Linguistic evaluations are illustrated in table 2 and 3, respectively.

Table 2. Linguistic and Fuzzy Scales for the Criteria

\begin{tabular}{|c|c|c|c|}
\hline Definition & \multicolumn{3}{|c|}{ Triangular Fuzzy Numbers } \\
\hline Equally important (EI) & 0.5 & 1 & 1.5 \\
\hline Weakly more important (WI) & 1 & 1.5 & 2 \\
\hline Strongly more important (SI) & 1.5 & 2 & 2.5 \\
\hline Very strongly more important (VI) & 2 & 2.5 & 3 \\
\hline Absolutely more important (AI) & 2.5 & 3 & 3.5 \\
\hline
\end{tabular}

Source: Chang (1996)

Linguistic choices of each decision makers for dimensions and criteria are illustrated in Tables 3-5.

Table 3. Linguistic Evaluations of Dimensions for pair-wise comparison matrix

\begin{tabular}{|c|c|c|c|c|c|c|c|c|}
\hline \multirow{2}{*}{} & \multicolumn{3}{|c|}{ Internal (Dimension 1) } & \multicolumn{3}{c|}{ External (Dimension 2) } \\
\cline { 2 - 9 } & DM1 & DM2 & DM3 & DM4 & DM1 & DM2 & DM3 & DM4 \\
\hline Internal (Dimension 1) & - & - & - & - & SI & WI & WI & SI \\
\hline External (Dimension 2) & & & & & - & - & - & - \\
\hline
\end{tabular}

Table 4. Linguistic Evaluations of The Criteria of Dimension 1 for pair-wise comparison matrix

\begin{tabular}{|c|c|c|c|c|c|c|c|c|c|c|c|c|}
\hline & \multicolumn{4}{|c|}{ Low Cost (Criterion 1) } & \multicolumn{4}{|c|}{$\begin{array}{c}\text { Organizational efficiency } \\
\text { (Criterion 2) }\end{array}$} & \multicolumn{4}{|c|}{$\begin{array}{l}\text { Technological infrastructure } \\
\text { (Criterion 3) }\end{array}$} \\
\hline & DM1 & DM2 & DM3 & DM4 & DM1 & DM2 & DM3 & DM4 & DM1 & DM2 & DM3 & DM4 \\
\hline $\begin{array}{l}\text { Low Cost } \\
\text { (Criterion 1) }\end{array}$ & - & - & - & - & VI & WI & SI & WI & WI & WI & WI & EI \\
\hline $\begin{array}{l}\text { Organizational } \\
\text { efficiency } \\
\text { (Criterion 2) }\end{array}$ & & - & - & - & - & - & - & - & WI & EI & WI & EI \\
\hline $\begin{array}{l}\text { Technological } \\
\text { infrastructure } \\
\text { (Criterion 3) }\end{array}$ & & & & & & & & & & . & - & - \\
\hline
\end{tabular}


Table 5. Linguistic Evaluations of the Criteria of Dimension 2 for pair-wise comparison matrix

\begin{tabular}{|c|c|c|c|c|c|c|c|c|c|c|c|c|}
\hline & \multicolumn{4}{|c|}{$\begin{array}{l}\text { Consistency of customer } \\
\text { expectations (Criterion 4) }\end{array}$} & \multicolumn{4}{|c|}{$\begin{array}{l}\text { Innovative services in } \\
\text { accordance with market } \\
\text { trends (Criterion 5) }\end{array}$} & \multicolumn{4}{|c|}{$\begin{array}{l}\text { Competitive Pricing } \\
\text { Policies (Criterion 6) }\end{array}$} \\
\hline & DM1 & DM2 & DM3 & DM4 & DM1 & DM2 & DM3 & DM4 & DM1 & DM2 & DM3 & DM4 \\
\hline $\begin{array}{l}\text { Consistency } \\
\text { of customer } \\
\text { expectations } \\
\text { (Criterion 4) }\end{array}$ & - & - & - & - & VI & WI & WI & SI & SI & WI & EI & WI \\
\hline $\begin{array}{l}\text { Innovative } \\
\text { services in } \\
\text { accordance } \\
\text { with market } \\
\text { trends } \\
\text { (Criterion 5) }\end{array}$ & & - & - & - & - & - & - & - & WI & WI & EI & SI \\
\hline $\begin{array}{l}\text { Competitive } \\
\text { Pricing } \\
\text { Policies } \\
\text { (Criterion 6) } \\
\end{array}$ & & & & & & & & & - & - & - & - \\
\hline
\end{tabular}

Step 3. Convert the linguistic scales of criteria and dimensions into the fuzzy numbers: Triangular fuzzy numbers are used for fuzzy pair-wise comparison matrices (Yıldırım et al., 2018). Fuzzy matrices are presented in appendix A-L. Averaged values of decision makers are considered to finalize the fuzzy pair-wise comparison and decision matrices. Tables 6-8 represent the averaged matrices for the dimensions, and criteria.

Table 6. Fuzzy pair-wise comparison matrix for the dimensions

\begin{tabular}{|c|c|c|c|c|c|c|}
\hline Dimensions & \multicolumn{3}{c|}{ Internal (Dimension 1) } & \multicolumn{3}{c|}{ External (Dimension 2) } \\
\hline Internal (Dimension 1) & 1.00 & 1.00 & 1.00 & 1.25 & 1.75 & 2.25 \\
\hline External (Dimension 2) & 0.45 & 0.58 & 0.83 & 1.00 & 1.00 & 1.00 \\
\hline
\end{tabular}

Table 7. Fuzzy pair-wise comparison matrix for the criteria of dimension 1

\begin{tabular}{|c|c|c|c|c|c|c|c|c|c|}
\hline Criteria & \multicolumn{3}{|c|}{$\begin{array}{c}\text { Low Cost } \\
\text { (Criteria 1) }\end{array}$} & \multicolumn{2}{c|}{$\begin{array}{c}\text { Organizational } \\
\text { efficiency } \\
\text { (Criteria 2) }\end{array}$} & \multicolumn{3}{c|}{$\begin{array}{c}\text { Technological } \\
\text { infrastructure } \\
\text { (Criteria 3) }\end{array}$} \\
\hline Low Cost (Criteria 1) & 1.00 & 1.00 & 1.00 & 1.38 & 1.88 & 2.38 & 0.88 & 1.38 & 1.88 \\
\hline $\begin{array}{c}\text { Organizational efficiency } \\
\text { (Criteria 2) }\end{array}$ & 0.43 & 0.56 & 0.79 & 1.00 & 1.00 & 1.00 & 0.75 & 1.25 & 1.75 \\
\hline $\begin{array}{c}\text { Technological infrastructure } \\
\text { (Criteria 3) }\end{array}$ & 0.54 & 0.75 & 1.25 & 0.58 & 0.83 & 1.50 & 1.00 & 1.00 & 1.00 \\
\hline
\end{tabular}


Table 8. Fuzzy pair-wise comparison matrix for the criteria of dimension 2

\begin{tabular}{|c|c|c|c|c|c|c|c|c|c|}
\hline Criteria & \multicolumn{2}{|c|}{$\begin{array}{c}\text { Consistency of customer } \\
\text { expectations (Criteria 4) }\end{array}$} & \multicolumn{2}{|c|}{$\begin{array}{c}\text { Innovative services in } \\
\text { accordance with market } \\
\text { trends (Criteria 5) }\end{array}$} & \multicolumn{3}{|c|}{$\begin{array}{c}\text { Competitive Pricing } \\
\text { Policies (Criteria 6) }\end{array}$} \\
\hline $\begin{array}{c}\text { Consistency of } \\
\text { customer } \\
\text { expectations (Criteria } \\
\text { 4) }\end{array}$ & 1.00 & 1.00 & 1.00 & 1.38 & 1.88 & 2.38 & 1.00 & 1.50 & 2.00 \\
\hline $\begin{array}{c}\text { Innovative services } \\
\text { in accordance with } \\
\text { market trends } \\
\text { (Criteria 5) }\end{array}$ & 0.43 & 0.56 & 0.79 & 1.00 & 1.00 & 1.00 & 1.00 & 1.50 & 2.00 \\
\hline $\begin{array}{c}\text { Competitive Pricing } \\
\text { Policies (Criteria 6) }\end{array}$ & 0.52 & 0.71 & 1.17 & 0.52 & 0.71 & 1.17 & 1.00 & 1.00 & 1.00 \\
\hline
\end{tabular}

Step 4. Compute the weights of criteria and dimensions: Chang's extended method (Chang, 1996) is applied for the computation process of fuzzy AHP and weighting results are provided in Table 9.

Table 9. Weights of criteria and dimensions for banking competitiveness

\begin{tabular}{|c|c|c|c|c|}
\hline \multirow{2}{*}{ Dimensions } & $\begin{array}{c}\text { Dimension } \\
\text { Weights }\end{array}$ & Criteria & $\begin{array}{c}\text { Local } \\
\text { Criteria } \\
\text { Weights }\end{array}$ & $\begin{array}{c}\text { Global } \\
\text { Weights }\end{array}$ \\
\hline \multirow{2}{*}{$\begin{array}{c}\text { Internal } \\
\text { (Dimension 1) }\end{array}$} & \multirow{2}{*}{0.86} & Low Cost (Criterion 1) & 0.463 & 0.397 \\
\hline \multirow{2}{*}{$\begin{array}{c}\text { External } \\
\text { (Dimension 2) }\end{array}$} & \multirow{2}{*}{0.14} & Organizational efficiency (Criterion 2) & 0.270 & 0.232 \\
\cline { 3 - 5 } & & $\begin{array}{c}\text { Technological infrastructure (Criterion 3) } \\
\text { Consistency of customer expectations } \\
\text { (Criterion 4) }\end{array}$ & 0.267 & 0.230 \\
\cline { 3 - 5 } & & $\begin{array}{c}\text { Innovative services in accordance with } \\
\text { market trends (Criterion 5) }\end{array}$ & 0.487 & 0.069 \\
\cline { 3 - 5 } & Competitive Pricing Policies (Criterion 6) & 0.213 & 0.042 \\
\hline
\end{tabular}

According to the results, internal perspective (dimension 1) is the most important factor with 86 percentage among the banking competitiveness dimensions whereas external factor (dimension 2) has relatively the weakest importance. However, Low cost (criterion 1) is placed first in the internal factor set by computing the results with 46.3 percentage while technological infrastructure (criterion 3) stays the last line. Consistency of customer expectations (criterion 4) is defined as the first important component with the result of 0.487 as competitive pricing policies (criterion 6 ) are at the last seat among the external factors of banking competitiveness.

Step 5. Provide the linguistic priorities of decision makers for the alternatives: Selected experts evaluates the alternative countries in the European zone by using the linguistic scales defined in Table 10.

Table 10. Linguistic and Fuzzy Scales for the Alternatives

\begin{tabular}{|c|c|c|c|}
\hline Definition & \multicolumn{3}{|c|}{ Triangular Fuzzy Numbers } \\
\hline Worst (W) & 0 & 0 & 2.5 \\
\hline Poor (P) & 0 & 2.5 & 5 \\
\hline Fair (F) & 2.5 & 5 & 7.5 \\
\hline Good (G) & 5 & 7.5 & 10 \\
\hline Best (B) & 7.5 & 10 & 10 \\
\hline
\end{tabular}

Source: Dinçer et. al. (2016) 
Linguistic evaluations of each decision maker are illustrated in Table 11.

Table 11. Linguistic evaluations of alternatives for the decision matrix

\begin{tabular}{|c|c|c|c|c|c|c|c|c|c|c|c|c|c|c|c|c|c|c|c|c|}
\hline \multirow{2}{*}{$\begin{array}{l}\text { Alternatives } \\
\text { /Criteria }\end{array}$} & \multicolumn{4}{|c|}{ Alternative 1 (United Kingdom) } & \multicolumn{4}{|c|}{ Alternative 2 (Germany) } & \multicolumn{4}{|c|}{ Alternative 3 (Italy) } & \multicolumn{4}{|c|}{ Alternative 4 (France) } & \multicolumn{4}{|c|}{ Alternative 5 (Spain) } \\
\hline & DM1 & DM2 & DM3 & DM4 & DM1 & DM2 & DM3 & DM4 & DM1 & DM2 & DM3 & DM4 & DM1 & DM2 & DM3 & DM4 & DM1 & DM2 & DM3 & DM4 \\
\hline $\mathrm{C} 1$ & $\mathrm{~F}$ & G & $\mathrm{F}$ & G & $\mathrm{F}$ & G & G & $\mathrm{F}$ & $\mathrm{F}$ & $\mathrm{F}$ & G & G & G & $\mathrm{F}$ & G & G & $\mathrm{F}$ & $\mathrm{P}$ & G & $\mathrm{F}$ \\
\hline $\mathrm{C} 2$ & G & $\mathrm{F}$ & G & G & G & G & G & B & $\mathrm{W}$ & G & B & B & G & $\mathrm{F}$ & $\mathrm{F}$ & G & G & G & $\mathrm{F}$ & $\mathrm{F}$ \\
\hline C3 & G & G & G & $\mathrm{F}$ & G & G & G & G & $\mathrm{F}$ & $\mathrm{F}$ & $\mathrm{F}$ & $\mathrm{F}$ & $\mathrm{F}$ & G & $\mathrm{F}$ & G & $\mathrm{F}$ & G & $\mathrm{F}$ & G \\
\hline $\mathrm{C} 4$ & $\mathrm{P}$ & $\mathrm{F}$ & $\mathrm{P}$ & $\mathrm{F}$ & $\mathrm{F}$ & G & $\mathrm{F}$ & $\mathrm{P}$ & $\mathrm{F}$ & $\mathrm{F}$ & G & G & $\mathrm{F}$ & G & $\mathrm{F}$ & G & G & G & $\mathrm{F}$ & $\mathrm{F}$ \\
\hline C5 & $\mathrm{F}$ & G & $\mathrm{F}$ & G & G & G & B & G & G & G & G & G & $\mathrm{F}$ & G & $\mathrm{F}$ & $\mathrm{F}$ & G & $\mathrm{F}$ & G & $\mathrm{F}$ \\
\hline
\end{tabular}

Step 6. Construct the fuzzy decision matrix: Triangular fuzzy numbers are stated by using the fuzzy scales in table 10 and the results of each decision maker are given in appendix M-P. Averaged values of decision makers are presented in Table 12.

Table 12. Fuzzy decision matrix

\begin{tabular}{|c|c|c|c|c|c|c|c|c|c|c|c|c|c|c|c|}
\hline & \multicolumn{3}{|c|}{ A1 } & \multicolumn{3}{|c|}{ A2 } & \multicolumn{3}{|c|}{ A3 } & \multicolumn{3}{|c|}{ A4 } & \multicolumn{3}{|c|}{ A5 } \\
\hline C1 & 3.75 & 6.25 & 8.75 & 3.75 & 6.25 & 8.75 & 3.75 & 6.25 & 8.75 & 4.38 & 6.88 & 9.38 & 2.50 & 5.00 & 7.50 \\
\hline C2 & 4.38 & 6.88 & 9.38 & 5.63 & 8.13 & 10.00 & 5.00 & 6.88 & 8.13 & 3.75 & 6.25 & 8.75 & 3.75 & 6.25 & 8.75 \\
\hline C3 & 4.38 & 6.88 & 9.38 & 5.00 & 7.50 & 10.00 & 2.50 & 5.00 & 7.50 & 3.75 & 6.25 & 8.75 & 3.75 & 6.25 & 8.75 \\
\hline C4 & 1.25 & 3.75 & 6.25 & 2.50 & 5.00 & 7.50 & 3.75 & 6.25 & 8.75 & 3.75 & 6.25 & 8.75 & 3.75 & 6.25 & 8.75 \\
\hline C5 & 3.75 & 6.25 & 8.75 & 5.63 & 8.13 & 10.00 & 5.00 & 7.50 & 10.00 & 3.13 & 5.63 & 8.13 & 3.75 & 6.25 & 8.75 \\
\hline C6 & 1.25 & 3.75 & 6.25 & 1.25 & 1.88 & $\begin{array}{l}4.38 \\
\end{array}$ & 5.00 & 7.50 & 10.00 & 3.75 & 6.25 & 8.75 & 4.38 & 6.88 & 9.38 \\
\hline
\end{tabular}

Step 7. Calculate the weighted values: the decision matrix is weighted with the results of fuzzy AHP. Table 13 and 14 show the normalized and weighted values of the decision matrix respectively.

Table 13. Normalized fuzzy decision matrix

\begin{tabular}{|l|c|c|c|c|c|c|c|c|c|}
\hline & \multicolumn{3}{|c|}{ C1 } & \multicolumn{3}{c|}{ C2 } & \multicolumn{3}{c|}{ C3 } \\
\hline A1 & 0.194 & 0.323 & 0.453 & 0.217 & 0.341 & 0.465 & 0.220 & 0.345 & 0.470 \\
\hline A2 & 0.194 & 0.323 & 0.453 & 0.279 & 0.403 & 0.496 & 0.251 & 0.376 & 0.502 \\
\hline A3 & 0.194 & 0.323 & 0.453 & 0.248 & 0.341 & 0.403 & 0.125 & 0.251 & 0.376 \\
\hline A4 & 0.226 & 0.356 & 0.485 & 0.186 & 0.310 & 0.434 & 0.188 & 0.314 & 0.439 \\
\hline A5 & 0.129 & 0.259 & 0.388 & 0.186 & 0.310 & 0.434 & 0.188 & 0.314 & 0.439 \\
\hline \multicolumn{7}{|c|}{ C4 } \\
\hline
\end{tabular}


Table 14. Weighted fuzzy decision matrix

\begin{tabular}{|l|l|l|l|l|l|l|l|c|c|}
\hline & \multicolumn{3}{|c|}{ C1 } & \multicolumn{3}{c|}{ C2 } & \multicolumn{3}{c|}{} \\
\hline A1 & 0.077 & 0.128 & 0.180 & 0.050 & 0.079 & 0.108 & 0.050 & 0.079 & 0.108 \\
\hline A2 & 0.077 & 0.128 & 0.180 & 0.065 & 0.093 & 0.115 & 0.058 & 0.086 & 0.115 \\
\hline A3 & 0.077 & 0.128 & 0.180 & 0.057 & 0.079 & 0.093 & 0.029 & 0.058 & 0.086 \\
\hline A4 & 0.090 & 0.141 & 0.193 & 0.043 & 0.072 & 0.101 & 0.043 & 0.072 & 0.101 \\
\hline A5 & 0.051 & 0.103 & 0.154 & 0.043 & 0.072 & 0.101 & 0.043 & 0.072 & 0.101 \\
\hline \multicolumn{7}{|c|}{ C4 } \\
\hline A1 & 0.005 & 0.014 & 0.024 & 0.008 & 0.013 & 0.018 & 0.002 & 0.006 & 0.010 \\
\hline A2 & 0.010 & 0.019 & 0.029 & 0.012 & 0.017 & 0.021 & 0.002 & 0.003 & 0.007 \\
\hline A3 & 0.014 & 0.024 & 0.033 & 0.010 & 0.015 & 0.021 & 0.008 & 0.013 & 0.017 \\
\hline A4 & 0.014 & 0.024 & 0.033 & 0.006 & 0.012 & 0.017 & 0.006 & 0.010 & 0.015 \\
\hline A5 & 0.014 & 0.024 & 0.033 & 0.008 & 0.013 & 0.018 & 0.007 & 0.012 & 0.016 \\
\hline
\end{tabular}

Step 8. List the ranking results: The values of the closeness coefficient are computed for each alternative and ranking results are provided by decreasing order of the closeness coefficient values. Table 15 shows the ranking results of alternatives.

Table 15. Ranking results of alternatives

\begin{tabular}{|c|c|c|c|c|}
\hline & $\boldsymbol{D}_{\boldsymbol{i}}^{*}$ & $\boldsymbol{D}_{\boldsymbol{i}}^{-}$ & $\boldsymbol{C C}_{\boldsymbol{i}}$ & Ranking \\
\hline A1 (United Kingdom) & 5.681 & 0.337 & 0.056 & 3 \\
\hline A2 (Germany) & 5.656 & 0.360 & 0.060 & 1 \\
\hline A3 (Italy) & 5.687 & 0.330 & 0.055 & 4 \\
\hline A4 (France) & 5.671 & 0.347 & 0.058 & 2 \\
\hline A5 (Spain) & 5.707 & 0.313 & 0.052 & 5 \\
\hline
\end{tabular}

The results represent that the performance of banking competitiveness in the Europe is ranked as Germany, France, United Kingdom, Italy, and Spain. Overall results demonstrate that alternative 2 (Germany) has the best rank among the selected countries in the European zone. However, alternative 5 (Spain) is listed at the last seat for the banking competitiveness.

\section{Conclusion}

The competitiveness of the European banking industry is measured in this study. For this purpose, 5 European countries, which have the highest GDP, are evaluated in this study that are Germany, France, United Kingdom, Italy, and Spain. The analysis process includes three different stages. Firstly, determinants of the competition in the banking industry are selected. In this process, a detailed literature review is performed. As a result, 6 different criteria are defined (3 internal and 3 external). In the second stage of the analysis, the significance of these dimensions and criteria is determined by using fuzzy AHP approach. In the final stage, fuzzy TOPSIS model is taken into consideration with the aim of ranking 5 biggest economies of Europe.

According to the results of fuzzy DEMATEL, it is identified that internal perspective (dimension 1) is much more important than the external factor (dimension 2). In addition to this issue, it is also determined that the criterion of low cost has the highest importance. However, competitive pricing policies (criterion 6) takes place on the last rank. On the other side, organizational efficiency (criterion 2) and technological infrastructure (criterion 3) are other significant criteria in comparison with the others. This situation summarizes that both internal factor and criteria related to this factor have an important influence on the competitiveness in the European banking industry.

The results of the fuzzy TOPSIS model indicate that Germany is on the first rank with respect to the competitiveness for banking industry. In addition to this issue, France has a second place in this ranking list. On the other hand, United Kingdom is the third country according to the competitive power in the banking industry. Furthermore, Italy and Spain are on the last rank regarding this condition. It can be understood from this situation that the countries, which have developed industry, have higher performance by comparing with the others. 
It is concluded that both internal factor and criteria related to this factor have an important influence on the competitiveness in the European banking industry. While considering this situation, it can be said that European banks should firstly concentrate on the cost effectiveness in order to increase the competitive power. For this purpose, these banks should make a detailed analysis of their expenses so that it can be easily understood which types of the costs are greater than the others. Therefore, necessary actions can be taken to decrease these costs. With the help of this issue, these banks can reduce their prices. This situation has an increasing influence on the competitive power.

This study focused on the 5 European countries, which have the highest GDP. In the future studies, this scope can be increased. For instance, all European countries can be taken into consideration. In addition to this situation, new methods can be used in the analysis process. For example, fuzzy DEMATEL approach can be considered to make a comparative analysis with the results of the fuzzy AHP. Similar to this situation, fuzzy MOORA and fuzzy VIKOR can be used so that it can be possible to compare the results with fuzzy TOPSIS (Eti, 2019). 


\section{BEYANLAR}

Hakem Değerlendirmesi: Dış bağımsız.

Çıkar Çatışması: Yazarlar tarafından çıkar çatışması bildirilmemiştir.

Finansal Destek: Yazarlar bu çalışma için finansal destek almadığını beyan etmiştir.

Katk1 Payı Oranı: Yarı yarıya (\%50/\%50)'dir. 


\section{REFERENCES}

Adams, A. M., Bashiru, M., \& Abdulai, I. A. (2016). Customer satisfaction in the banking industry in Ghana: A case of GCB bank limited in Wa municipality. Journal of Social Science Studies, 3(2), 217.

Agolla, J. E., Makara, T., \& Monametsi, G. (2018). Impact of banking innovations on customer attraction, satisfaction and retention: the case of commercial banks in Botswana. International Journal of Electronic Banking, 1(2), 150-170.

Alshubaily, N. F., \& Altameem, A. A. (2017). The Role of Strategic Information Systems (SIS) in Supporting and Achieving the Competitive Advantages (CA): An Empirical Study on Saudi Banking Sector. Int. J. Adv. Comput. Sci. Apllocations, 8(7), 128-139.

Awasthi, A., Govindan, K., \& Gold, S. (2018). Multi-tier sustainable global supplier selection using a fuzzy AHPVIKOR based approach. International Journal of Production Economics, 195, 106-117.

Bapat, D. (2017). Linking strategic orientation with performance: Implication for Indian banks. Strategic Change, 26(4), 403-411.

Basheer, M. F., Hussain, T., Hussan, S. G., \& Javed, M. (2015). Impact of customer awareness, competition and interest rate on growth of Islamic banking in Pakistan. International Journal of Scientific \& Technology Research, 4(8), 33-40.

Bereznoi, A. (2015). Business model innovation in corporate competitive strategy. Problems of Economic Transition, 57(8), 14-33.

Beskese, A., Demir, H. H., Ozcan, H. K., \& Okten, H. E. (2015). Landfill site selection using fuzzy AHP and fuzzy TOPSIS: a case study for Istanbul. Environmental Earth Sciences, 73(7), 3513-3521.

Bos, J. W., Kolari, J. W., \& Van Lamoen, R. C. (2013). Competition and innovation: Evidence from financial services. Journal of Banking \& Finance, 37(5), 1590-1601.

Burks, J. J., Cuny, C., Gerakos, J., \& Granja, J. (2018). Competition and voluntary disclosure: Evidence from deregulation in the banking industry. Review of Accounting Studies, 23(4), 1471-1511.

Carbó, S., Humphrey, D., Maudos, J., \& Molyneux, P. (2009). Cross-country comparisons of competition and pricing power in European banking. Journal of International Money and Finance, 28(1), 115-134.

Chang, D. Y. (1996). Applications of the extent analysis method on fuzzy AHP. European journal of operational research, 95(3), 649-655.

Chen, J. F., Hsieh, H. N., \& Do, Q. H. (2015). Evaluating teaching performance based on fuzzy AHP and comprehensive evaluation approach. Applied Soft Computing, 28, 100-108.

Chiaramonte, L., \& Casu, B. (2017). Capital and liquidity ratios and financial distress. Evidence from the European banking industry. The British Accounting Review, 49(2), 138-161.

Claessens, S., \& Van Horen, N. (2015). The impact of the global financial crisis on banking globalization. IMF Economic Review, 63(4), 868-918.

Coccorese, P., \& Pellecchia, A. (2013). Multimarket contact, competition and pricing in banking. Journal of International Money and Finance, 37, 187-214.

Cornaggia, J., Mao, Y., Tian, X., \& Wolfe, B. (2015). Does banking competition affect innovation?. Journal of financial economics, 115(1), 189-209.

Dal Colle, A. (2018). The mechanics of commercial banking liberalization and growth. Journal of Banking \& Finance, 86, 194-203.

Dinçer, H., \& Yüksel, S. (2018). Comparative evaluation of BSC-based new service development competencies in Turkish banking sector with the integrated fuzzy hybrid MCDM using content analysis. International Journal of Fuzzy Systems, 20(8), 2497-2516. 
Dinçer, H., \& Yüksel, S. (2019a). Multidimensional evaluation of global investments on the renewable energy with the integrated fuzzy decision-making model under the hesitancy. International Journal of Energy Research, 43(5), 1775-1784.

Dincer, H., \& Yuksel, S. (2019b). Balanced scorecard-based analysis of investment decisions for the renewable energy alternatives: A comparative analysis based on the hybrid fuzzy decision-making approach. Energy, 175, 1259-1270.

Dinçer, H., \& Yüksel, S. (2019c). An integrated stochastic fuzzy MCDM approach to the balanced scorecardbased service evaluation. Mathematics and Computers in Simulation.

Dincer, H., Hacioglu, U., \& Yuksel, S. (2016). Balanced scorecard-based performance assessment of Turkish banking sector with analytic network process. International Journal of Decision Sciences \& ApplicationsIJDSA, 1(1), 1-21.

Dinçer, H., Hacıoğlu, Ü., \& Yüksel, S. (2016b). The Impacts of Financial Variables on Employment Planning in Turkish Banking Sector. International Journal of Sustainable Entrepreneurship and Corporate Social Responsibility (IJSECSR), 1(2), 1-20.

Dinçer, H., Hacıoğlu, Ü., \& Yüksel, S. (2017). A Strategic Approach to Global Financial Crisis in Banking Sector: A Critical Appraisal of Banking Strategies Using Fuzzy ANP and Fuzzy Topsis Methods. International Journal of Sustainable Economies Management (IJSEM), 6(1), 1-21.

Dinçer, H., Hacıoğlu, Ü., \& Yüksel, S. (2017b). Türk Bankacılık Sektöründe Dengeli Skorkart Temelli Yeni Hizmet Geliştirme Yetkinliğinin Bulanık Mantık Çerçevesinde Hibrit Çok Kriterli Karar Verme Yöntemiyle Karşılaştırmalı Analizi. Bankacılar Dergisi, 103, 3-33.

Dincer, H., Hacioglu, U., Tatoglu, E., \& Delen, D. (2016). A fuzzy-hybrid analytic model to assess investors' perceptions for industry selection. Decision Support Systems, 86, 24-34.

Dinçer, H., Yüksel, S., \& Martínez, L. (2019). Analysis of Balanced Scorecard-based SERVQUAL Criteria based on Hesitant Decision-making Approaches. Computers \& Industrial Engineering.

Dincer, H., Yüksel, S., \& Martinez, L. (2019d). Balanced scorecard-based Analysis about European Energy Investment Policies: A hybrid hesitant fuzzy decision-making approach with Quality Function Deployment. Expert Systems with Applications, 115, 152-171.

Dinçer, H., Yüksel, S., Eti, S., \& Tula, A. (2019f). Effects of Demographic Characteristics on Business Success: An Evidence From Turkish Banking Sector. In Handbook of Research on Business Models in Modern Competitive Scenarios (pp. 304-324). IGI Global.

Dinçer, H., Yüksel, S., Kartal, M. T., \& Alpman, G. (2019e). Corporate Governance-Based Evaluation of Alternative Distribution Channels in the Turkish Banking Sector Using Quality Function Deployment With an Integrated Fuzzy MCDM Method. In Intergenerational Governance and Leadership in the Corporate World: Emerging Research and Opportunities(pp. 39-77). IGI Global.

Dincer, Hasan, and Umit Hacioglu. "Performance evaluation with fuzzy VIKOR and AHP method based on customer satisfaction in Turkish banking sector." Kybernetes 42.7 (2013): 1072-1085.

Ervural, B. C., Zaim, S., Demirel, O. F., Aydin, Z., \& Delen, D. (2018). An ANP and fuzzy TOPSIS-based SWOT analysis for Turkey's energy planning. Renewable and Sustainable Energy Reviews, 82, 1538-1550.

Eti, S. (2019). The Use of Quantitative Methods in Investment Decisions: A Literature Review. In Handbook of Research on Global Issues in Financial Communication and Investment Decision Making (pp. 256-275). IGI Global.

Eti, S., Dinçer, H., \& Yüksel, S. (2019). G20 Ülkelerinde Bankacılık Sektörünün 5 Yıllık Geleceğinin Arıma Yöntemi İle Tahmin Edilmesi. Uluslararası Hukuk ve Sosyal Bilim Araştırmaları Dergisi, 1(1), 26-38.

Eti, S., Kalkavan, H., Dinçer, H., \& Yüksel, S. (2020). Predicting the Role of Islamic Banking on Sustainable Economic Development: An Analysis for Turkey With ARIMA Model. In Handbook of Research on Creating Sustainable Value in the Global Economy (pp. 146-164). IGI Global. 
Fernández, R. O., \& Garza-García, J. G. (2015). The relationship between bank competition and financial stability: a case study of the Mexican banking industry. Ensayos Revista de Economía (Ensayos Journal of Economics), 34(1), 103-120.

Fontin, J. R., \& Lin, S. W. (2019). Comparison of banking innovation in low-income countries: A meta-frontier approach. Journal of Business Research, 97, 198-207.

Ghosh, A. (2017). How does banking sector globalization affect economic growth?. International Review of Economics \& Finance, 48, 83-97.

Gozman, D., Liebenau, J., \& Mangan, J. (2018). The innovation mechanisms of fintech start-ups: insights from SWIFT's innotribe competition. Journal of Management Information Systems, 35(1), 145-179.

Gunasekaran, A., Subramanian, N., \& Papadopoulos, T. (2017). Information technology for competitive advantage within logistics and supply chains: A review. Transportation Research Part E: Logistics and Transportation Review, 99, 14-33.

Guo, S., \& Zhao, H. (2015). Optimal site selection of electric vehicle charging station by using fuzzy TOPSIS based on sustainability perspective. Applied Energy, 158, 390-402.

Gupta, H., \& Barua, M. K. (2017). Supplier selection among SMEs on the basis of their green innovation ability using BWM and fuzzy TOPSIS. Journal of Cleaner Production, 152, 242-258.

Hes, A., \& Jílková, P. (2016). Position of Low-Cost Banks on the Financial Market in the Czech Republic. European Research Studies, 19(4), 42.

Hu, T., \& Xie, C. (2016). Competition, innovation, risk-taking, and profitability in the chinese banking sector: An empirical analysis based on structural equation modeling. Discrete Dynamics in Nature and Society, 2016.

Hwang, C.L. K. Yoon. (1981). Multiple Attributes Decision Making Methods and Applications. Springer, Berlin Heidelberg.

Jun, Q., Dinçer, H., \& Yüksel, S. (2020). Stochastic hybrid decision-making based on interval type 2 fuzzy sets for measuring the innovation capacities of financial institutions. International Journal of Finance \& Economics.

Kalkavan, H. (2020). The Relation Between Corporate Social Responsibility and Financial Performance: Reviewing Empirical Studies and Discussing the Ethical Aspect. In Strategic Outlook for Innovative Work Behaviours (pp. 179-191). Springer, Cham.

Kalkavan, H., \& Ersin, I. (2019). Determination of Factors Affecting the South East Asian Crisis of 1997 ProbitLogit Panel Regression: The South East Asian Crisis. In Handbook of Research on Global Issues in Financial Communication and Investment Decision Making (pp. 148-167). IGI Global.

Kalkavan, H., Eti, Serkan, \& Yüksel, S. (2020). Türkiye'deki Bankacilik Sektörü, Sanayi Gelişimi ve Ekonomik Büyüme Arasindaki İlişkinin VAR Analizi ile İncelenmesi. Akademik Araştırmalar ve Çalışmalar Dergisi (AKAD), 12(22), 56-74.

Karabag, S. F. (2019). Factors impacting firm failure and technological development: A study of three emergingeconomy firms. Journal of Business Research, 98, 462-474.

Kasasbeh, E. A., Harada, Y., \& Noor, I. M. (2017). Developing A Conceptual Model For the Relationship Between Human Resource Management, E-Business Strategies and Competitive Advantage. The Journal of Internet Banking and Commerce, 22(1).

Kasımoğlu, M., Göre, Z. S., \& Altın, E. (2016). Competitiveness Analysis of Istanbul Financial Center. ProcediaSocial and Behavioral Sciences, 235, 771-781.

Kim, J. B., Ma, M. L., \& Wang, H. (2015). Financial development and the cost of equity capital: Evidence from China. China Journal of Accounting Research, 8(4), 243-277.

Kotarba, M. (2016). New factors inducing changes in the retail banking customer relationship management (CRM) and their exploration by the FinTech industry. Foundations of management, 8(1), 69-78.

Li, X., Zhu, S., Yüksel, S., Dinçer, H., \& Ubay, G. G. (2020). Kano-based mapping of innovation strategies for renewable energy alternatives using hybrid interval type-2 fuzzy decision-making approach. Energy, 211, 118679. 
Li, Y. X., Wu, Z. X., Dinçer, H., Kalkavan, H., \& Yüksel, S. (2021). Analyzing TRIZ-based strategic priorities of customer expectations for renewable energy investments with interval type-2 fuzzy modeling. Energy Reports, 7, 95-108.

Lima-Junior, F. R., \& Carpinetti, L. C. R. (2016). Combining SCOR® model and fuzzy TOPSIS for supplier evaluation and management. International Journal of Production Economics, 174, 128-141.

Litvintseva, G. P., \& Gakhova, N. A. (2016, October). Trends in high-technologic industries development in Russia. In 2016 13th International Scientific-Technical Conference on Actual Problems of Electronics Instrument Engineering (APEIE) (Vol. 3, pp. 256-262). IEEE.

Mangla, S. K., Kumar, P., \& Barua, M. K. (2015). Risk analysis in green supply chain using fuzzy AHP approach: A case study. Resources, Conservation and Recycling, 104, 375-390.

Mosadeghi, R., Warnken, J., Tomlinson, R., \& Mirfenderesk, H. (2015). Comparison of Fuzzy-AHP and AHP in a spatial multi-criteria decision making model for urban land-use planning. Computers, Environment and Urban Systems, 49, 54-65.

Nowakowski, M., \& Karasiewicz, G. (2016). Market structure and price-cost margins in European retail gasoline industry. Journal of Management and Business Administration, 24(3), 105-124.

Parameswar, N., Dhir, S., \& Dhir, S. (2017). Banking on innovation, innovation in banking at ICICI bank. Global Business and Organizational Excellence, 36(2), 6-16.

Paul, J., Mittal, A., \& Srivastav, G. (2016). Impact of service quality on customer satisfaction in private and public sector banks. International Journal of Bank Marketing, 34(5), 606-622.

Perçin, S., \& Aldalou, E. (2018). Financial Performance Evaluation of Turkish Airline Companies Using Integrated Fuzzy AHP Fuzzy TOPSIS Model. Uluslararast İktisadi ve İdari Incelemeler Dergisi,(18. EYI Özel Sayıs), 583-598.

Qiu, D., Dinçer, H., Yüksel, S., \& Ubay, G. G. (2020). Multi-Faceted Analysis of Systematic Risk-Based Wind Energy Investment Decisions in E7 Economies Using Modified Hybrid Modeling with IT2 Fuzzy Sets. Energies, 13(6), 1423.

Rahman, A. (2017). Assessment of Self-Service Banking in Bangladesh: Are Private Commercial Banks One Step Further Building Customer Centric Model or Becoming Money Making Machines in Market Competition?. Available at SSRN 2919778.

Raičević, B., Ignjatijević, S., \& Milojević, I. (2016). Financial analysis of foreign direct investment on economic growth of developing countries. Economics of agriculture, 63(2), 649-663.

Saaty, T. L. (1977). A scaling method for priorities in hierarchical structures. Journal of mathematical psychology, 15(3), 234-281.

Schliephake, E. (2016). Capital regulation and competition as a moderator for banking stability. Journal of Money, Credit and Banking, 48(8), 1787-1814.

Şengül, Ü., Eren, M., Shiraz, S. E., Gezder, V., \& Şengül, A. B. (2015). Fuzzy TOPSIS method for ranking renewable energy supply systems in Turkey. Renewable Energy, 75, 617-625.

Setyawati, I., Widyastuti, T., Suryati, A., \& Hartani, N. (2019). Intellectual capital performance of Islamic banks in Indonesia: Towards competitive advantages. Management Science Letters, 9(12), 1999-2008.

Sircar, S., Agrawal, R., Shanthi, S. K., Reddy, K. S., Bapat, D., \& Mazumdar, D. (2015). Assessment of business strategy: Implication for Indian banks. Journal of Strategy and Management.

Stenbacka, R., \& Takalo, T. (2019). Switching costs and financial stability. Journal of Financial Stability, 41, 1424.

Sudha, K., \& Kavita, A. (2019). Implementation of Business Process Re-engineering and its impact on Financial Performance of Banks (With Special Reference to State Bank of India). Advances in Management, 12(1), 71-73. 
Suhidayat, T., Affandi, A., \& Sidharta, I. (2016). Service Quality on Customer Value; Perspective from Rural Banking Sectors in Bandung, Indonesia. International Journal of Academic Research in Business and Social Sciences, 6(12), 609-616.

Tadeu, H. F. B., Duarte, A. L. D. C. M., Taurion, C., \& Jamil, G. L. (2019). Digital Transformation: Digital Maturity Applied to Study Brazilian Perspective for Industry 4.0. In Best Practices in Manufacturing Processes (pp. 3-27). Springer, Cham.

Tan, Y., \& Floros, C. (2018). Risk, competition and efficiency in banking: Evidence from China. Global Finance Journal, 35, 223-236.

Vera-Gilces, P., Camino-Mogro, S., Ordeñana-Rodríguez, X., \& Cornejo-Marcos, G. (2019). A look inside banking profitability: Evidence from a dollarized emerging country. The Quarterly Review of Economics and Finance.

Vives, X. (2019). Competition and Stability in Modern Banking: A Post-Crisis Perspective. International Journal of Industrial Organization.

Vozková, K., \& Teplý, P. (2018). Determinants of bank fee income in the EU banking industry-does market concentration matter?. Prague Economic Papers, 27(1), 3-20.

Wang, C., Zhou, H., Dınçer, H., Yüksel, S., Ubay, G. G., \& Uluer, G. S. (2020). Analysis of electricity pricing in emerging economies with hybrid multi-criteria decision-making technique based on interval-valued intuitionistic hesitant fuzzy sets. IEEE Access, 8, 190882-190896.

Wu, L., \& Chiu, M. L. (2015). Organizational applications of IT innovation and firm's competitive performance: A resource-based view and the innovation diffusion approach. Journal of Engineering and Technology Management, 35, 25-44.

Yıldırım, H., Aydoğan, H., Özcan, S., \& Eti, S. (2018). Fazi Kontrol Grafikleri İle Klasik Kontrol Grafiklerinin Karşılaştırılması Üzerine Bir Deneme. Journal of Research in Business, 3(2), 150-173.

Yilmaz, A. (2016). The Impact Of Hris Usage On Organizational Efficiency And Employee Performance: A Research In Industrial And Banking Sector In Ankara And Istanbul Cities. International Journal of Business and Management, 4(4), 14-52.

Yuan, J., Zhang, Z. M., Yüksel, S., \& Dinçer, H. (2020). Evaluating recognitive balanced scorecard-based quality improvement strategies of energy investments with the integrated hesitant 2-tuple interval-valued pythagorean fuzzy decision-making approach to QFD. IEEE Access, 8, 171112-171128.

Yuksel, S., Dincer, H., \& Hacioglu, U. (2015). CAMELS-based Determinants for the Credit Rating of Turkish Deposit Banks. International Journal of Finance \& Banking Studies, 4(4), 1-19.

Yüksel, S., Dinçer, H., \& Meral, Y. (2019). Financial analysis of international energy trade: a strategic outlook for EU-15. Energies, 12(3), 431.

Yuliansyah, Y., Rammal, H. G., \& Rose, E. (2016). Business strategy and performance in Indonesia's service sector. Journal of Asia Business Studies, 10(2), 164-182.

Zhong, J., Hu, X., Yüksel, S., Dinçer, H., \& Ubay, G. G. (2020). Analyzing the investments strategies for renewable energies based on multi-criteria decision model. IEEE Access, 8, 118818-118840.

Zuhroh, I., Ismail, M., \& Maskie, G. (2015). Cost Efficiency of Islamic Banks in Indonesia-A Stochastic Frontier Analysis. Procedia-Social and Behavioral Sciences, 211, 1122-1131.

Zyoud, S. H., Kaufmann, L. G., Shaheen, H., Samhan, S., \& Fuchs-Hanusch, D. (2016). A framework for water loss management in developing countries under fuzzy environment: Integration of Fuzzy AHP with Fuzzy TOPSIS. Expert Systems with Applications, 61, 86-105. 


\section{Appendix}

Appendix A. Fuzzy pair-wise comparison matrix for the dimensions by decision maker 1

\begin{tabular}{|c|c|c|c|c|c|c|}
\hline Dimensions & \multicolumn{3}{|c|}{ Internal (Dimension 1) } & \multicolumn{3}{c|}{ External (Dimension 2) } \\
\hline Internal (Dimension 1) & 1.00 & 1.00 & 1.00 & 1.5 & 2 & 2.5 \\
\hline External (Dimension 2) & 0.40 & 0.50 & 0.67 & 1.00 & 1.00 & 1.00 \\
\hline
\end{tabular}

Appendix B. Fuzzy pair-wise comparison matrix for the dimensions by decision maker 2

\begin{tabular}{|c|c|c|c|c|c|c|}
\hline Dimensions & \multicolumn{3}{|c|}{ Internal (Dimension 1) } & \multicolumn{3}{c|}{ External (Dimension 2) } \\
\hline Internal (Dimension 1) & 1.00 & 1.00 & 1.00 & 1 & 1.5 & 2 \\
\hline External (Dimension 2) & 0.50 & 0.67 & 1.00 & 1.00 & 1.00 & 1.00 \\
\hline
\end{tabular}

Appendix C. Fuzzy pair-wise comparison matrix for the dimensions by decision maker 3

\begin{tabular}{|c|c|c|c|c|c|c|}
\hline Dimensions & \multicolumn{3}{|c|}{ Internal (Dimension 1) } & \multicolumn{3}{c|}{ External (Dimension 2) } \\
\hline Internal (Dimension 1) & 1.00 & 1.00 & 1.00 & 1 & 1.5 & 2 \\
\hline External (Dimension 2) & 0.50 & 0.67 & 1.00 & 1.00 & 1.00 & 1.00 \\
\hline
\end{tabular}

Appendix D. Fuzzy pair-wise comparison matrix for the dimensions by decision maker 4

\begin{tabular}{|c|c|c|c|c|c|c|}
\hline Dimensions & \multicolumn{3}{|c|}{ Internal (Dimension 1) } & \multicolumn{3}{c|}{ External (Dimension 2) } \\
\hline Internal (Dimension 1) & 1.00 & 1.00 & 1.00 & 1.5 & 2 & 2.5 \\
\hline External (Dimension 2) & 0.40 & 0.50 & 0.67 & 1.00 & 1.00 & 1.00 \\
\hline
\end{tabular}

Appendix E. Fuzzy pair-wise comparison matrix for the criteria of Dimension 1 by decision maker 1

\begin{tabular}{|c|c|c|c|c|c|c|c|c|c|}
\hline \multirow{2}{*}{ Criteria } & \multicolumn{3}{|c|}{$\begin{array}{c}\text { Low Cost } \\
\text { (Criteria 1) }\end{array}$} & \multicolumn{2}{c|}{$\begin{array}{c}\text { Organizational } \\
\text { efficiency } \\
\text { (Criteria 2) }\end{array}$} & \multicolumn{3}{c|}{$\begin{array}{c}\text { Technological } \\
\text { infrastructure } \\
\text { (Criteria 3) }\end{array}$} \\
\hline Low Cost (Criteria 1) & 1.00 & 1.00 & 1.00 & 2 & 2.5 & 3 & 1 & 1.5 & 2 \\
\hline $\begin{array}{c}\text { Organizational efficiency (Criteria } \\
\text { 2) }\end{array}$ & 0.33 & 0.40 & 0.50 & 1.00 & 1.00 & 1.00 & 1 & 1.5 & 2 \\
\hline $\begin{array}{c}\text { Technological infrastructure } \\
\text { (Criteria 3) }\end{array}$ & 0.50 & 0.67 & 1.00 & 0.50 & 0.67 & 1.00 & 1.00 & 1.00 & 1.00 \\
\hline
\end{tabular}

Appendix F. Fuzzy pair-wise comparison matrix for the criteria of Dimension 1 by decision maker 2

\begin{tabular}{|c|c|c|c|c|c|c|c|c|c|}
\hline \multirow{2}{*}{ Criteria } & \multicolumn{3}{|c|}{$\begin{array}{c}\text { Low Cost } \\
\text { (Criteria 1) }\end{array}$} & \multicolumn{3}{c|}{$\begin{array}{c}\text { Organizational } \\
\text { efficiency } \\
\text { (Criteria 2) }\end{array}$} & \multicolumn{3}{c|}{$\begin{array}{c}\text { Technological } \\
\text { infrastructure } \\
\text { (Criteria 3) }\end{array}$} \\
\hline Low Cost (Criteria 1) & 1.00 & 1.00 & 1.00 & 1 & 1.5 & 2 & 1 & 1.5 & 2 \\
\hline $\begin{array}{c}\text { Organizational efficiency (Criteria } \\
\text { 2) }\end{array}$ & 0.50 & 0.67 & 1.00 & 1.00 & 1.00 & 1.00 & 0.5 & 1 & 1.5 \\
\hline $\begin{array}{c}\text { Technological infrastructure } \\
\text { (Criteria 3) }\end{array}$ & 0.50 & 0.67 & 1.00 & 0.67 & 1.00 & 2.00 & 1.00 & 1.00 & 1.00 \\
\hline
\end{tabular}


Appendix G. Fuzzy pair-wise comparison matrix for the criteria of Dimension 1 by decision maker 3

\begin{tabular}{|c|c|c|c|c|c|c|c|c|c|}
\hline \multirow{2}{*}{ Criteria } & \multicolumn{3}{|c|}{$\begin{array}{c}\text { Low Cost } \\
\text { (Criteria 1) }\end{array}$} & \multicolumn{2}{c|}{$\begin{array}{c}\text { Organizational } \\
\text { efficiency } \\
\text { (Criteria 2) }\end{array}$} & \multicolumn{2}{c|}{$\begin{array}{c}\text { Technological } \\
\text { infrastructure } \\
\text { (Criteria 3) }\end{array}$} \\
\hline Low Cost (Criteria 1) & 1.00 & 1.00 & 1.00 & 1.5 & 2 & 2.5 & 1 & 1.5 & 2 \\
\hline $\begin{array}{c}\text { Organizational efficiency (Criteria } \\
\text { 2) }\end{array}$ & 0.40 & 0.50 & 0.67 & 1.00 & 1.00 & 1.00 & 1 & 1.5 & 2 \\
\hline $\begin{array}{c}\text { Technological infrastructure } \\
\text { (Criteria 3) }\end{array}$ & 0.50 & 0.67 & 1.00 & 0.50 & 0.67 & 1.00 & 1.00 & 1.00 & 1.00 \\
\hline
\end{tabular}

Appendix H. Fuzzy pair-wise comparison matrix for the criteria of Dimension 1 by decision maker 4

\begin{tabular}{|c|c|c|c|c|c|c|c|c|c|}
\hline \multirow{2}{*}{ Criteria } & \multicolumn{3}{c|}{$\begin{array}{c}\text { Low Cost } \\
\text { (Criteria 1) }\end{array}$} & \multicolumn{2}{c|}{$\begin{array}{c}\text { Organizational } \\
\text { efficiency } \\
\text { (Criteria 2) }\end{array}$} & \multicolumn{3}{c|}{$\begin{array}{c}\text { Technological } \\
\text { infrastructure } \\
\text { (Criteria 3) }\end{array}$} \\
\hline Low Cost (Criteria 1) & 1.00 & 1.00 & 1.00 & 1 & 1.5 & 2 & 0.5 & 1 & 1.5 \\
\hline $\begin{array}{c}\text { Organizational efficiency (Criteria } \\
\text { 2) }\end{array}$ & 0.50 & 0.67 & 1.00 & 1.00 & 1.00 & 1.00 & 0.5 & 1 & 1.5 \\
\hline $\begin{array}{c}\text { Technological infrastructure } \\
\text { (Criteria 3) }\end{array}$ & 0.67 & 1.00 & 2.00 & 0.67 & 1.00 & 2.00 & 1.00 & 1.00 & 1.00 \\
\hline
\end{tabular}

Appendix I. Fuzzy pair-wise comparison matrix for the criteria of Dimension 2 by decision maker 1

\begin{tabular}{|c|c|c|c|c|c|c|c|c|c|}
\hline \multirow{2}{*}{$\begin{array}{c}\text { Criteria } \\
\text { Consistency of } \\
\text { customer } \\
\text { expectations (Criteria } \\
4 \text { ) }\end{array}$} & \multicolumn{3}{|c|}{$\begin{array}{c}\text { Consistency of } \\
\text { customer expectations } \\
\text { (Criteria 4) }\end{array}$} & \multicolumn{3}{|c|}{$\begin{array}{l}\text { Innovative services in } \\
\text { accordance with } \\
\text { market trends } \\
\text { (Criteria 5) }\end{array}$} & \multicolumn{3}{|c|}{$\begin{array}{l}\text { Competitive Pricing } \\
\text { Policies (Criteria 6) }\end{array}$} \\
\hline & 1.00 & 1.00 & 1.00 & 2 & 2.5 & 3 & 1.5 & 2 & 2.5 \\
\hline $\begin{array}{l}\text { Innovative services in } \\
\text { accordance with } \\
\text { market trends } \\
\text { (Criteria 5) }\end{array}$ & 0.33 & 0.40 & 0.50 & 1.00 & 1.00 & 1.00 & 1 & 1.5 & 2 \\
\hline $\begin{array}{l}\text { Competitive Pricing } \\
\text { Policies (Criteria 6) }\end{array}$ & 0.40 & 0.50 & 0.67 & 0.50 & 0.67 & 1.00 & 1.00 & 1.00 & 1.00 \\
\hline
\end{tabular}


Appendix J. Fuzzy pair-wise comparison matrix for the criteria of Dimension 2 by decision maker 2

\begin{tabular}{|c|c|c|c|c|c|c|c|c|c|}
\hline \multirow{2}{*}{\begin{tabular}{|c|} 
Criteria \\
Consistency of \\
customer \\
expectations (Criteria \\
4 )
\end{tabular}} & \multicolumn{3}{|c|}{$\begin{array}{l}\text { Consistency of } \\
\text { customer } \\
\text { expectations } \\
\text { (Criteria 4) } \\
\end{array}$} & \multicolumn{3}{|c|}{$\begin{array}{c}\text { Innovative services in } \\
\text { accordance with } \\
\text { market trends } \\
\text { (Criteria 5) }\end{array}$} & \multicolumn{3}{|c|}{$\begin{array}{l}\text { Competitive Pricing } \\
\text { Policies (Criteria 6) }\end{array}$} \\
\hline & 1.00 & 1.00 & 1.00 & 1 & 1.5 & 2 & 1 & 1.5 & 2 \\
\hline $\begin{array}{l}\text { Innovative services } \\
\text { in accordance with } \\
\text { market trends } \\
\text { (Criteria 5) }\end{array}$ & 0.50 & 0.67 & 1.00 & 1.00 & 1.00 & 1.00 & 1 & 1.5 & 2 \\
\hline $\begin{array}{l}\text { Competitive Pricing } \\
\text { Policies (Criteria 6) }\end{array}$ & 0.50 & 0.67 & 1.00 & 0.50 & 0.67 & 1.00 & 1.00 & 1.00 & 1.00 \\
\hline
\end{tabular}

Appendix K. Fuzzy pair-wise comparison matrix for the criteria of Dimension 2 by decision maker 3

\begin{tabular}{|c|c|c|c|c|c|c|c|c|c|}
\hline Criteria & & $\begin{array}{l}\text { sisten } \\
\text { istom } \\
\text { ectat } \\
\text { riteri }\end{array}$ & & $\begin{array}{r}\text { Inno } \\
\text { acc } \\
\mathrm{m}\end{array}$ & $\begin{array}{l}\text { ive se } \\
\text { danc } \\
\text { ket tr } \\
\text { riteri }\end{array}$ & $\begin{array}{l}\text { ces in } \\
\text { ith } \\
\text { ds }\end{array}$ & $\begin{array}{l}\text { Com } \\
\text { Poli }\end{array}$ & $\begin{array}{l}\text { titive } \\
\text { (Cri }\end{array}$ & $\begin{array}{l}\text { icing } \\
\text { ia 6) }\end{array}$ \\
\hline $\begin{array}{c}\text { Consistency of } \\
\text { customer } \\
\text { expectations (Criteria } \\
4 \text { ) }\end{array}$ & 1.00 & 1.00 & 1.00 & 1 & 1.5 & 2 & 0.5 & 1 & 1.5 \\
\hline $\begin{array}{l}\text { Innovative services } \\
\text { in accordance with } \\
\text { market trends } \\
\text { (Criteria 5) }\end{array}$ & 0.50 & 0.67 & 1.00 & 1.00 & 1.00 & 1.00 & 0.5 & 1 & 1.5 \\
\hline $\begin{array}{l}\text { Competitive Pricing } \\
\text { Policies (Criteria 6) }\end{array}$ & 0.67 & 1.00 & 2.00 & 0.67 & 1.00 & 2.00 & 1.00 & 1.00 & 1.00 \\
\hline
\end{tabular}

Appendix L. Fuzzy pair-wise comparison matrix for the criteria of Dimension 2 by decision maker 4

\begin{tabular}{|c|c|c|c|c|c|c|c|c|c|}
\hline \multirow{2}{*}{\begin{tabular}{|c|} 
Criteria \\
Consistency of \\
customer \\
expectations (Criteria \\
4) \\
\end{tabular}} & \multicolumn{3}{|c|}{$\begin{array}{l}\text { Consistency of } \\
\text { customer } \\
\text { expectations } \\
\text { (Criteria 4) }\end{array}$} & \multicolumn{3}{|c|}{$\begin{array}{l}\text { Innovative services in } \\
\text { accordance with } \\
\text { market trends } \\
\text { (Criteria 5) }\end{array}$} & \multicolumn{3}{|c|}{$\begin{array}{l}\text { Competitive Pricing } \\
\text { Policies (Criteria 6) }\end{array}$} \\
\hline & 1.00 & 1.00 & 1.00 & 1.5 & 2 & 2.5 & 1 & 1.5 & 2 \\
\hline $\begin{array}{l}\text { Innovative services } \\
\text { in accordance with } \\
\text { market trends } \\
\text { (Criteria 5) }\end{array}$ & 0.40 & 0.50 & 0.67 & 1.00 & 1.00 & 1.00 & 1.5 & 2 & 2.5 \\
\hline $\begin{array}{l}\text { Competitive Pricing } \\
\text { Policies (Criteria 6) }\end{array}$ & 0.50 & 0.67 & 1.00 & 0.40 & 0.50 & 0.67 & 1.00 & 1.00 & 1.00 \\
\hline
\end{tabular}


Appendix M. Fuzzy decision matrix by decision maker 1

\begin{tabular}{|c|c|c|c|c|c|c|c|c|c|c|c|c|c|c|c|}
\hline & \multicolumn{3}{|c|}{ A1 } & \multicolumn{3}{|c|}{ A2 } & \multicolumn{3}{|c|}{ A3 } & \multicolumn{3}{|c|}{ A4 } & \multicolumn{3}{|c|}{ A5 } \\
\hline C1 & 2.5 & 5 & 7.5 & 2.5 & 5 & 7.5 & 2.5 & 5 & 7.5 & 5 & 7.5 & 10 & 2.5 & 5 & 7.5 \\
\hline C2 & 5 & 7.5 & 10 & 5 & 7.5 & 10 & 0 & 0 & 2.5 & 5 & 7.5 & 10 & 5 & 7.5 & 10 \\
\hline C3 & 5 & 7.5 & 10 & 5 & 7.5 & 10 & 2.5 & 5 & 7.5 & 2.5 & 5 & 7.5 & 2.5 & 5 & 7.5 \\
\hline C4 & 0 & 2.5 & 5 & 2.5 & 5 & 7.5 & 2.5 & 5 & 7.5 & 2.5 & 5 & 7.5 & 5 & 7.5 & 10 \\
\hline C5 & 2.5 & 5 & 7.5 & 5 & 7.5 & 10 & 5 & 7.5 & 10 & 2.5 & 5 & 7.5 & 5 & 7.5 & 10 \\
\hline C6 & 0 & 2.5 & 5 & 0 & 0 & 2.5 & 5 & 7.5 & 10 & 5 & 7.5 & 10 & 5 & 7.5 & 10 \\
\hline
\end{tabular}

Appendix N. Fuzzy decision matrix by decision maker 2

\begin{tabular}{|c|c|c|c|c|c|c|c|c|c|c|c|c|c|c|c|}
\hline & \multicolumn{3}{|c|}{ A1 } & \multicolumn{3}{|c|}{ A2 } & \multicolumn{3}{|c|}{ A3 } & \multicolumn{3}{|c|}{ A4 } & \multicolumn{3}{|c|}{ A5 } \\
\hline C1 & 2.5 & 5 & 7.5 & 2.5 & 5 & 7.5 & 2.5 & 5 & 7.5 & 5 & 7.5 & 10 & 2.5 & 5 & 7.5 \\
\hline C2 & 5 & 7.5 & 10 & 5 & 7.5 & 10 & 0 & 0 & 2.5 & 5 & 7.5 & 10 & 5 & 7.5 & 10 \\
\hline C3 & 5 & 7.5 & 10 & 5 & 7.5 & 10 & 2.5 & 5 & 7.5 & 2.5 & 5 & 7.5 & 2.5 & 5 & 7.5 \\
\hline C4 & 0 & 2.5 & 5 & 2.5 & 5 & 7.5 & 2.5 & 5 & 7.5 & 2.5 & 5 & 7.5 & 5 & 7.5 & 10 \\
\hline C5 & 2.5 & 5 & 7.5 & 5 & 7.5 & 10 & 5 & 7.5 & 10 & 2.5 & 5 & 7.5 & 5 & 7.5 & 10 \\
\hline C6 & 0 & 2.5 & 5 & 0 & 0 & 2.5 & 5 & 7.5 & 10 & 5 & 7.5 & 10 & 5 & 7.5 & 10 \\
\hline
\end{tabular}

Appendix O. Fuzzy decision matrix by decision maker 3

\begin{tabular}{|c|c|c|c|c|c|c|c|c|c|c|c|c|c|c|c|}
\hline & \multicolumn{4}{|c|}{ A1 } & \multicolumn{4}{|c|}{ A2 } & \multicolumn{3}{c|}{ A3 } & \multicolumn{3}{c|}{ A4 } & \multicolumn{3}{c|}{ A5 } \\
\hline C1 & 2.5 & 5 & 7.5 & 2.5 & 5 & 7.5 & 2.5 & 5 & 7.5 & 5 & 7.5 & 10 & 2.5 & 5 & 7.5 \\
\hline C2 & 5 & 7.5 & 10 & 5 & 7.5 & 10 & 0 & 0 & 2.5 & 5 & 7.5 & 10 & 5 & 7.5 & 10 \\
\hline C3 & 5 & 7.5 & 10 & 5 & 7.5 & 10 & 2.5 & 5 & 7.5 & 2.5 & 5 & 7.5 & 2.5 & 5 & 7.5 \\
\hline C4 & 0 & 2.5 & 5 & 2.5 & 5 & 7.5 & 2.5 & 5 & 7.5 & 2.5 & 5 & 7.5 & 5 & 7.5 & 10 \\
\hline C5 & 2.5 & 5 & 7.5 & 5 & 7.5 & 10 & 5 & 7.5 & 10 & 2.5 & 5 & 7.5 & 5 & 7.5 & 10 \\
\hline C6 & 0 & 2.5 & 5 & 0 & 0 & 2.5 & 5 & 7.5 & 10 & 5 & 7.5 & 10 & 5 & 7.5 & 10 \\
\hline
\end{tabular}

Appendix P. Fuzzy decision matrix by decision maker 4

\begin{tabular}{|c|c|c|c|c|c|c|c|c|c|c|c|c|c|c|c|}
\hline & \multicolumn{4}{|c|}{ A1 } & \multicolumn{3}{|c|}{ A2 } & \multicolumn{3}{c|}{ A3 } & \multicolumn{3}{c|}{ A4 } & \multicolumn{3}{c|}{ A5 } \\
\hline C1 & 2.5 & 5 & 7.5 & 2.5 & 5 & 7.5 & 2.5 & 5 & 7.5 & 5 & 7.5 & 10 & 2.5 & 5 & 7.5 \\
\hline C2 & 5 & 7.5 & 10 & 5 & 7.5 & 10 & 0 & 0 & 2.5 & 5 & 7.5 & 10 & 5 & 7.5 & 10 \\
\hline C3 & 5 & 7.5 & 10 & 5 & 7.5 & 10 & 2.5 & 5 & 7.5 & 2.5 & 5 & 7.5 & 2.5 & 5 & 7.5 \\
\hline C4 & 0 & 2.5 & 5 & 2.5 & 5 & 7.5 & 2.5 & 5 & 7.5 & 2.5 & 5 & 7.5 & 5 & 7.5 & 10 \\
\hline C5 & 2.5 & 5 & 7.5 & 5 & 7.5 & 10 & 5 & 7.5 & 10 & 2.5 & 5 & 7.5 & 5 & 7.5 & 10 \\
\hline C6 & 0 & 2.5 & 5 & 0 & 0 & 2.5 & 5 & 7.5 & 10 & 5 & 7.5 & 10 & 5 & 7.5 & 10 \\
\hline
\end{tabular}

